Vol. 10 No. 2 Juli 2021

E-ISSN: 2502-3101 P-ISSN: 2302-528x

http: //ojs.unud.ac.id/index.php/jmhu

\title{
Vote Buying dalam Pemilihan Kepala Desa dan Upaya Penangkalannya : Studi Kasus di Kabupaten Tabanan
}

\author{
Piers Andreas Noak ${ }^{1}$
}

1Fakultas Ilmu Sosial dan Ilmu Politik Universitas Udayana, E-mail: andreas.noak@yahoo.com

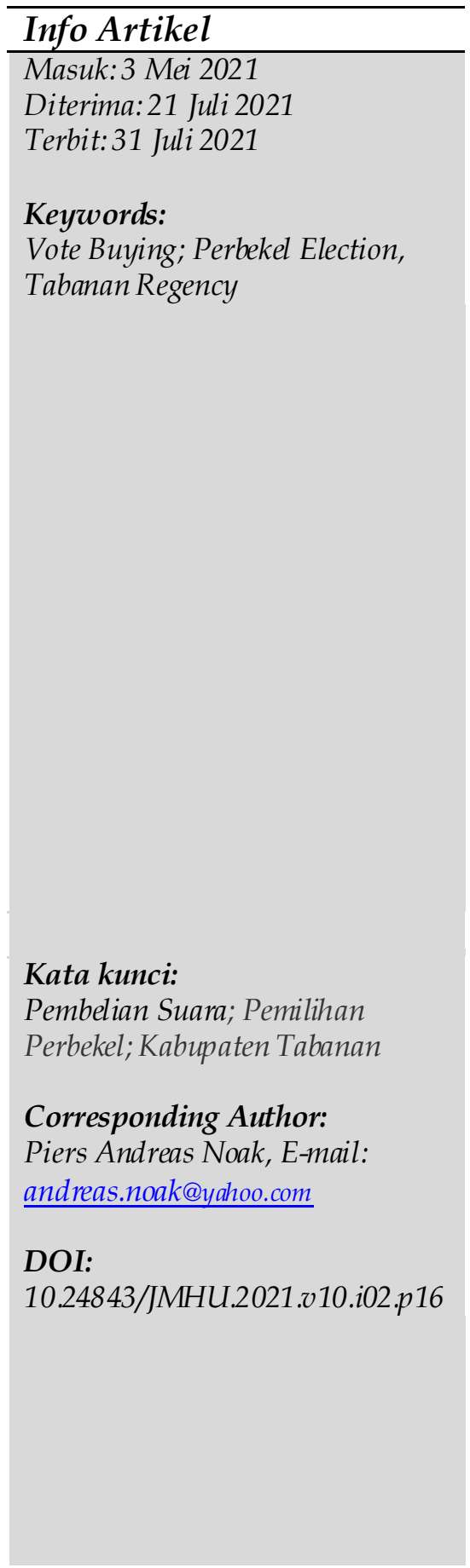

\begin{abstract}
This article aims to analyze the potential for the practice of buying and selling votes or vote buying in the election of village heads or Perbekel in Tabanan Regency, Bali. This article explores regulatory aspects, views, and variations that occur in society, including efforts to reduce the practice of buying and selling votes. In recent years, in every holding of village head elections or perbekel in several areas, there are always vote buying practices and various activities. To answer this question, the study in this article uses empirical legal research which analyzes the implementation of the law regarding village head elections regulation in reality in the community with a focus on two villages in Tabanan Regency, Bali. This article uses interview and documentation for data collection techniques and uses a rational choice institutionalism framework. With this theoretical framework, it tells the empirical facts that the calculated practice of buying votes is determined by calculations that are all profitable for the candidates and the voters. The opportunity for this practice to occur is considered to be large, carried out by perbekel officers with incumbent status. There are several offers to reduce this problem, namely by using a special website that manages the election of perbekel by loading the profile of the perbekel candidates specifically to ensure the accountability of the election.
\end{abstract}

\begin{tabular}{l}
\hline Abstrak \\
\hline Artikel ini bertujuan untuk menganalisis potensi terjadinya \\
praktik jual beli suara atau vote buying dalam pemilihan \\
kepala desa atau perbekel di Kabupaten Tabanan, Provinsi \\
Bali. Artikel ini mengeksplorasi aspek regulasi, pandangan, \\
dan ragam benturan yang terjadi di masyarakat termasuk \\
upaya-upaya pereduksian praktik jual beli suara tersebut. \\
Pada beberapa tahun belakangan, pada setiap \\
penyelenggaraan pemilihan kepala desa atau perbekel serentak \\
pada beberapa wilayah senantiasa di ikuti oleh adanya \\
praktik-praktik jual beli suara atau vote buying dengan \\
beragam bentuk aktifitasnya. Untuk menjawab persoalan \\
tersebut, studi pada artikel ini menggunakan penelitian \\
hukum empiris dimana menganalisis implementasi hukum \\
terkait pelaksanaan regulasi pemilihan kepala desa dalam \\
realitasnya di masyarakat dengan fokus dua desa di \\
Kabupaten Tabanan, Bali. Artikel ini menggunakan teknik \\
pengumpulan data wawancara dan dokumentasi serta
\end{tabular}


dianalisis menggunakan frame teoritik rational choice institusionalism. Melalui frame teoritik ini memperlihatkan fakta empirik bahwa praktik vote buying dianggap turut ditentukan oleh kalkulasi-kalkulasi yang serba menguntungkan baik bagi kalangan kandidat maupun masyarakat pemilihnya. Peluang terjadinya praktik ini dianggap berpotensi besar dilakukan oknum perbekel yang berstatus incumbent. Terdapat beberapa tawaran mereduksi persoalan ini, yaitu dengan pemanfaatan website khusus yang mengelola pemilihan perbekel dengan memuat profil perbekel secara khusus untuk menjamin akuntabilitas pemilihan.

\section{Pendahuluan}

Pemilihan kepala desa adalah salah satu rutinitas proses demokrasi prosedural yang berjalan di negara kita. Hanya saja elektorasi yang berlangsung di level akar rumput ini dianggap kurang bergaung dibandingkan perhelatan rutin pemilihan kepala daerah seperti pemilihan Bupati, Walikota, maupun Gubernur. Intensitas media memberitakan dinamika perhelatan pemilihan kepada desa, baik dari siklus pentahapan, penilaian rekam jejak kandidat, hingga fase penetapan hasil pemilihan, justru tersisih oleh berita-berita dinamika politik yang berlangsung pada tataran kekuasaan makro. Persepsi mayoritas yang terbangun kuat di kalangan warga dimana elektorasi pemimpin di wilayah desa sekedar rutinitas program yang dilaksanakan oleh pemerintah kabupaten sekaligus hanya sebagai penggenap syarat administratif daripada kepentingan untuk mewujudkan substansi penyelenggaraan demokrasi lokal yang notabene melibatkan partisipasi langsung warga pada level akar rumput.

Persepsi mayoritas tersebut tentu sifatnya menjadi paradoksal mengingat secara hakiki desa adalah soko guru atau penyangga berjalannya sistem pemerintahan negara Indonesia. Hal ini sekaligus pula, warga pada lapis paling bawah ini, yaitu warga desa, senantiasa langsung berinteraksi dengan perangkat desanya sebagai penyelenggara layanan publik yang paling intens dan sekaligus terdekat dengan mereka. Warga desa yang terdaftar sebagai pemilih potensial pada setiap rutinitas elektorasi di level lokal, seperti pemilihan umum kepala daerah atau pemilihan umum legislatif, sebagian besar berdomisili di wilayah pedesaan. Pada konteks inilah, maka Negara, --dalam hal ini Pemerintah--, seharusnya mempunyai komitmen untuk mengatur proses elektorasi ini secara partisipatif sekaligus memiliki aspek-aspek akuntabilitas yang bisa dipertanggungjawabkan. Elektorasi langsung di tingkat lokal diyakini akan dapat meningkatkan kualitas kedaulatan maupun partisipasi rakyat. Masyarakat desa, sebagai warga di level akar rumput, dapat menentukan dan memilih calon yang dianggap terbaik dalam memperjuangkan kepentingan mereka sendiri secara otonom. ${ }^{1}$ Hingga saat ini peraturan normatif tentang elektorasi pimpinan desa atau kepala desa, atau di Bali disebut sebagai pemilihan perbekel, secara khusus diatur melalui regulasi di level Pemerintah Pusat dan Pemerintah Daerah. Regulasi yang ada di level Pemerintah Pusat terimplementasi pada Peraturan Menteri Dalam Negeri

\footnotetext{
${ }^{1}$ Kompas, "Pilkada Langsung Serentak: Sejarah Dan Perkembangannya Di Indonesia," accessed April 18, 2021, https://kompaspedia.kompas.id/baca/paparan-topik/pilkada-langsungserentak-sejarah-dan-perkembangannya-di-indonesia.k
} 
Republik Indonesia Nomor 65 Tahun 2017 tentang Perubahan atas Permendagri Nomor 112 Tahun 2014 tentang Pemilihan Kepala Desa.

Pada pengaturan Pasal 30 regulasi ini memang memuat rambu-rambu aturan berupa etika maupun sanksi atas pelanggaran proses pelaksanaan pemilihan pimpinan desa (kepala desa). Hanya saja secara implementatif, proses elektorasi kepala desa beserta segenap proses perhelatannya yang diselenggarakan serentak di setiap kabupaten ini, seringkali memiliki pola penyimpangan (deviasi) atau benturan yang kurang lebih sama dengan pemilihan kepala daerah yang berada di level atasnya, seperti pemilihan kepala daerah bupati dan wakil bupati, walikota dan wakil walikota, ataupun gubernur dan wakil gubernur. Tercatat di dalam penelusuran data media oleh penulis, muncul beragam aduan aktivitas penyimpangan elektorasi di tingkat desa, seperti misalnya indikasi keberpihakan panitia pemilihan pada salah satu calon, kecurangan dalam pemutakhiran data pemilih, perselisihan atau gugatan hasil pemilihan, hingga celah munculnya aktivitas vote buying pada saat masa sosialisasi dan menjelang pelaksanaan elektorasi kepala desa. Vote buying merupakan aktivitas memberikan kompensasi berupa materi. Materi tersebut bisa berwujud beragam rupa, seperti uang atau iming-iming barang yang diberikan terhadap seseorang, kelompok orang, atau bahkan keluarga yang notabene mempunyai hak untuk memilih di hari pencoblosan atau penyaluran suara maupun yang dilakukan pada hari sebelum waktu pelaksanaan elektorasi. Intinya, pada praktik vote buying ini terdapat aktifitas jual beli hak pilih suara yang ditawarkan oleh seorang kandidat pemilihan pada ranah elektorasi. ${ }^{2}$

Artikel ini secara spesifik membahas praktik vote buying dalam pemilihan kepala desa atau perbekel. Meski dianggap sebagai bentuk pelanggaran yang menciderai praktik demokrasi, praktik ini justru menunjukkan kenaikan signifikan pada setiap periodenya. Pada kurun tahun 2017 misalnya, terdapat beberapa laporan aduan praktik vote buying di beberapa pemilihan kepala desa seperti pada wilayah Demak, wilayah Indragiri Hilir, wilayah Kebumen serta wilayah lainnya di Indonesia. Praktik ini didominasi pemberian imbalan uang dengan rentang jumlah lima puluh ribu rupiah hingga lima ratus ribu rupiah setiap individu atau per suara. ${ }^{3}$ Pada tahun 2019 dan 2020, tercatat pula beberapa kasus terkait vote buying yang aktifitasnya marak pada wilayah desa-desa di kabupaten maupun kota di Indonesia, dengan praktikpraktik yang beragam bentuknya. Bentuk-bentuk ini khas dan seringkali menyertakan relasi kuasa yang berlangsung halus dan termanifestasi pada berbagai aktifitas, seperti club goods, pork barrel politics, hingga programmatic politics. ${ }^{4}$

Praktik vote buying sendiri yang menjadi pembahasan utama artikel ini adalah praktik yang seringkali muncul dalam pemilihan kepala desa serentak, termasuk yang berlangsung di wilayah Bali, dimana di Bali istilah pemilihan kepala desa ini memiliki penyebutan secara spesifik sebagai pemilihan perbekel. Setidaknya pada lima tahun terakhir, terdapat beberapa kasus aduan yang kasusnya menonjol di masyarakat Bali.

\footnotetext{
2 Edward Aspinall and Noor Rohman, "Village Head Elections in Java: Money Politics and Brokerage in the Remaking of Indonesia's Rural Elite," Journal of Southeast Asian Studies 48, no. 1 (2017): 31-52, https://doi.org/https://doi.org/https://doi.org/ $10.1017 /$ S0022463416000461.

3 Kompas, "Besaran Politik Uang Pilkades Di Demak Rp 50.000-500.000 per Pemilih," accessed January 31, 2021, https:/ / regional.kompas.com/read/2017/10/02/08355381/ besaran-politikuang-pilkades-di-demak-rp-50000-500000-per-pemilihan.s.

${ }^{4}$ Mada Sukmajati and E Aspinal, "Politik Uang Di Indonesia," Yogyakarta: PolGov, 2015.
} 
Beberapa karakteristik aduan yang muncul pada pemilihan perbekel yang sempat mencuat di Bali adalah yang terjadi di Kabupaten Tabanan dan Kota Denpasar. Pada kedua wilayah ini aduan yang muncul didominasi praktik kecurangan kandidat termasuk di dalamnya aduan praktik vote buying terutama dalam bentuk pembagian uang jelang pemilihan yang besarannya dalam rentang nominal seratus ribu rupiah hingga dua juta rupiah.

Bahkan dalam praktik ini diindikasikan pula adanya aktivitas campur tangan oknum fungsionaris partai politik maupun pejabat di level kabupaten dan kota tertentu dimana pada akhirnya segenap aktivitas ini menyertakan dan sekaligus mengarah pada aktivitas vote buying. Pada beberapa media, juga diulas terdapat perbekel yang setelah dilantik langsung dicopot dari jabatannya karena terindikasi kasus penyalahgunaan wewenang perbekel mengelola keuangan desa selama tahun anggaran 2014 dan 2015 sehingga mengakibatkan kerugian negara sebesar Rp 194 juta lebih. Akibatnya, oknum perbekel ini dipenjara karena dinyatakan bersalah menciderai Pasal 3 juncto Pasal 18 UU Tipikor, juncto Pasal 55 ayat (1) ke-1 KUHP, juncto Pasal 64 ayat (1) KUHP. 5

Praktik vote buying ini memang selalu menyertakan iming-iming uang atau barang yang dilakukan oleh kandidat kepada para pemilihnya. Pada beberapa kajian studi yang ditelusuri penulis menegaskan bahwa praktik jual beli suara ini merupakan masalah besar bagi berprosesnya demokrasi di level akar rumpur tingkat lokal, khususnya desa. Sehingga menjadi sangat perlu untuk menganalisis tidak saja bagaimana potensi kerawanan praktik vote buying ini berlangsung, melainkan juga sangat perlu untuk mengetahui bagaimana upaya-upaya penanganannya.

Pada kajian-kajian pustaka yang selama ini ada, praktik vote buying banyak dikaji dalam banyak varian metodologis termasuk perspektif yang digunakan. Salah satu studi yang menegaskan adanya praktik ini adalah studi Takeuchi (2013). ${ }^{6}$ Pada studinya, Takeuchi menyatakan kecenderungan para calon pada fase elektorasi pimpinan lokal di RRC secara sengaja memilih menjalankan vote buying terutama ketika mereka melakukan persaingan dalam pemilihan kepala distrik, semacam desa. Ironisnya praktik ini jarang diangkat sebagai persoalan publik, bahkan sudah dianggap sebagai kebiasaan yang melembaga di dalam proses elektorasi di tataran akar rumput. Studi yang sama dikaji pula oleh Bowie yang menegaskan aktifitas vote buying pada wilayah Thailand realitasnya telah melekat kuat bahkan menjadi "bagian budaya politik" yang melembaga di desa-desa tradisional di Thailand. ${ }^{7}$ Akhirnya sikap apatis memilih maupun berpartisipasi sebagai kandidat, berakar dari ketidaktahuan warga terhadap proses ini. Terdapat ketiadaan minat warga desa termasuk enggan memprotes praktik korupsi yang terjadi dalam bentuk jual beli suara hingga menganggap wajar segala bentuk praktik vote buying ini. Warga lebih banyak

\footnotetext{
5 Ali Mustofa, "Baru Dilantik Langsung Dicopot Jadi Perbekel, Ashari Diganjar 15 Bulan," accessed December 4, 2020, https://radarbali.jawapos.com/read/2019/12/19/170880/barudilantik-langsung-dicopot-ja di-perbekel-ashari-diganjar-15-bulan.

${ }^{6}$ Hiroki Takeuchi, "Vote Buying, Village Elections, and Authoritarian Rule in Rural China: A Game-Theoretic Analysis," Journal of East Asian Studies 13, no. 1 (2013): 69-105, https://doi.org/https://doi.org/10.1017/S1598240800008535. p. 69.

7 Katherine A Bowie, "Vote Buying and Village Outrage in an Election in Northem Thailand: Recent Legal Reforms in Historical Context," The Journal of Asian Studies 67, no. 2 (2008): 469-511, https:// doi.org/10.1017/S0021911808000673. p.469-482.
} 
mendiamkan praktik vote buying dalam rutinitas elektorasi di tingkat lokal meski keberadaannya telah 'diketahui bersama' dapat berpotensi mengancam demokrasi. Warga lebih banyak mendiamkan praktik vote buying dalam rutinitas elektorasi di tingkat lokal meski keberadaannya telah 'diketahui bersama' dapat berpotensi mengancam demokrasi.

Studi-studi yang mempunyai kedekatan kajian dengan artikel ini adalah studi dari Haili yang menegaskan adanya aktivitas vote buying yang pada akhirnya menyertakan sifat anti demokrasi dimana berpeluang besar menciderai aspek-aspek demokrasi substantif maupun prosedural. Melalui riset bermetode kualitatif deskriptif, Haili menegaskan aktivitas vote buying berjalan massif dan intensif bahkan keberadaannya berpotensi untuk menggerakkan maupun meningkatkan angka keikutsertaan pemilih dalam proses elektorasi. Hanya saja, dicatat dalam studi Haili ini pula bahwa keikusertaan tersebut semata-mata bersifat semu (pseudo-participation). Hal ini karena di dalamnya mengandung ketidakrasionalitasan dalam memilih dan sekaligus menyebabkan tergiringnya opini publik bahwa politik elektorasi mengandung biaya yang mahal. Hal ini karena terdapat biaya tinggi yang mesti ditanggung peserta (kandidat) elektorasi jika ingin memenangkan kompetisi tersebut yaitu tidak lain dengan aktivitas membeli hak suara dari para pemilih. Hal inilah yang kemudian mendorong adanya kesemuan demokrasi atau pseudo democracy. Fenomena di saat mekanisme berjalannya demokrasi prosedural pada akhirnya tidak selalu menjamin terwujudnya demokrasi substantif atau hakiki. Beberapa pengamat maupun dalam studi Haili menyebutnya sebagai demokrasi hybrid. Situasi dimana prosedur-prosedur demokrasi akhirnya bercampur baur dengan aktifitas non demokrasi. ${ }^{8}$

Kajian lain mengenai pemilihan kepala desa pernah distudikan pula oleh Aspinal dan Rahman yang berjenis kualitatif deskriptif dengan membahas bentuk-bentuk elektorasi pada level desa di Jawa Tengah. Pada elektorasi ini pada akhirnya disebutkan Aspinal dan Rahman menyertakan praktik vote buying yang memberikan peluang kepada peserta pemilihan atau kandidat yang berkompetisi hanyalah yang memiliki kemampuan modal kuat sekaligus jaringan luas dengan para pejabat di level daerah hingga level atas (pemerintah pusat). ${ }^{9}$

Pada perkembangannya, studi-studi mengenai aktivitas vote buying atau jual beli hak suara untuk kasus Indonesia masih cenderung didekati oleh kajian pada level elektorasi kepala daerah, Bupati, Walikota, atau Gubernur. Studi tersebut seperti studi Shahab (2016) termasuk pula secara spesifik untuk kasus Bali terdapat studi dari Widnyani (2015). Studi Shahab (2016) menegaskan kuantitas aduan vote buying pada setiap waktu yang cenderung meningkat terutama pada kasus pemilihan kepala daerah di Indonesia. Praktik jual beli suara atau vote buying distudikan sebagai temuan yang bermuara pada instrumen guna mengkompensasi hak pemilih dalam bentuk iming-iming uang ataupun barang sebagai konsekuensi aktifitas pemilih yang pilihannya memiliki motif pada rasionalitas material ekonomi.

Studi yang bermetode studi kasus dan sekaligus disampaikan dalam narasi utama kuantitatif, Shahab menegaskan bahwa pada elektorasi di tingkat lokal, responden

\footnotetext{
8 Halili Halili, "Praktik Politik Uang Dalam Pemilihan Kepala Desa," Jurnal Penelitian Humaniora 14, no. 2 (October 1, 2009): 99-112, https://joumal.uny.acid/index.php/humaniora/article/view/21770.

${ }_{9}$ Aspinall and Rohman, "Village Head Elections in Java: Money Politics and Brokerage in the Remaking of Indonesia's Rural Elite."
} 
penelitian yang berdomisili di wilayah desa berpeluang memberikan ruang bagi keberlangsungan aktivitas politik uang dan jual beli suara (vote buying) dibandingkan dengan penduduk yang berdomisili di kota. Pada studi Shahab ini penulis mengkritisi studinya yang sebenarnya terkesan menyederhanakan elemen pendorong dan sekaligus mengabaikan perbedaan pandangan atas wacana (discourse) terkait praktik jual beli suara yang tentunya sangat dinamis. ${ }^{10}$

Studi Widnyani (2015) mengenai analisis politik uang di Kabupaten Gianyar lebih banyak mendeskripsikan temuan mekanisme vote buying pada elektorasi kepala daerah di Bali. Vote buying berjalan di dalam dua bentuk, dengan bentuk langsung dimana kandidat beroperasi dengan memiliki orang kepercayaan melalui tim pemenangan dan calo pemilihan (broker). Elemen pendorong vote buying dalam studi ini diakibatkan oleh keinginan mendapat penghargaan sekaligus aktualisasi diri kandidat, selain pula adanya dorongan atas kepentingan fisiologis kelompok pemenangan dan broker suara sekaligus kepentingan mendapatkan rasa aman dari para pemilih. ${ }^{11}$

Kajian-kajian yang sifatnya makro terkait praktik jual beli suara dilakukan oleh Takeuchi (2013). Takeuchi melakukan studi di wilayah China dimana ia mengamati praktik jual beli suara pada elektorasi di tingkat desa lebih terdorong oleh keberadaan elit desa yang terkategorisasi ke dalam elit politik, elit ekonomi, serta elit sosial. Keberadaan elit-elit tersebut memiliki kekuasaan yang sangat berpengaruh pada keberadaan pengusaha yang ada di wilayah desa setempat atau elit yang memegang peran penting dalam hubungan kekerabatan. Para elit ini memiliki potensi mengakses penyediaan barang-barang publik yang bersandar pada sumber dayanya masingmasing, misalnya dengan penggunaan kewenangan politik, sumber daya material ekonomi, termasuk pula potensi kekerabatan masyarakat setempat. Segenap potensi ini yang digunakan sebagai dasar pertukaran material bagi berlangsungnya praktik jual beli suara guna memenangkan kompetisi elektorasi di level desa.

Sama halnya dengan studi diatas, studi Bowie menegaskan adanya aspek jual beli suara sebagai bagian alur kesejarahan pada waktu lampau yang berlangsung hingga masa sekarang (path dependency). ${ }^{12}$ Praktik ini diyakini tertanam kuat di kalangan masyarakat sebagai kolektif memori serta sangat susah dihilangkan begitu saja. Di dalam kondisi ini, praktik jual beli suara merupakan mata rantai yang senantiasa berkesinambungan dan termanifestasi pada elemen pelaksanaan elektorasi khususnya pemilihan jabatan publik tertentu. Elemen pendorong dari kondisi ini adalah akibat tapak kehadiran pemerintah kolonial di masa lalu sehingga kemudian mendorong terdapatnya penguasaan material oleh sebagian atau sedikit orang yang kemudian

${ }^{10}$ A Shahab, "Vote Buying Dalam Pemilihan Kepala Daerah (Pilkada) Studi Kasus Pilkada Surabaya Dan Pilkada Kabupaten Blitar Tahun 2010," Jurnal Jejaring Administrasi Publik 4, no. 2 (November 2012): 118-24, http://joumal.unair.ac.id/ADMP@vote-buying-dalampemilihan-kepala-daerah-(pilkada)-studi-kasus-pilkada-surabaya-dan-pilkada-kabupatenblitar-tahun-2010-article-9418-media-81-category-8.html.

11 Widnyani, "KPU Gianyar Gelar Publikasi Hasil Riset Tingkat Partisipasi Pemilih Pemilu 2014 - Situs Resmi Komisi Pemilihan Umum Kabupaten Gianyar," accessed December 5, 2020, http://www.kpu-gianyarkab.goid/ berita/bacaberita/95/kpu-gianyar-gelarpublikasi-hasil-riset-tingkat-partisipasi-pemilih-pemilu-2014 html.

12 Bowie, "Vote Buying and Village Outrage in an Election in Northern Thailand: Recent Legal Reforms in Historical Context.".p.469 . 
dijuluki sebagai elit. Studi yang sedikit berbeda dengan studi diatas adalah studi dari Callahan. Callahan dalam studinya lebih banyak mengeksplorasi dorongan persepsional yang muncul pada kalangan masyarakat pemilih, para calon pemimpin yang berkompetisi sekaligus para panitia pemilihan khususnya berkaitan dengan upaya untuk mengantisipasi jual beli suara dalam pemilihan kepala desa atau distrik. Studi Callahan memaparkan praktik jual beli suara pada negara-negara belum maju atau sedang berkembang yang notabene kondisi para pemilih, calon, maupun panitia penyelenggara masih termotifasi oleh kalkulasi untung rugi atau pertimbangan rasionalitas ekonomi.

Pada wilayah negara Argentina, Callahan menyebutkan bahwa desa banyak menjadi praktik sasaran jual beli suara dimana menyerang masyarakat yang masih mempunyai keraguan pada calon pemimpin yang diusung sehingga dirinya bisa berpotensi untuk pindah dukungan ke calon pemimpin lain sehingga disebutnya sebagai pemilih acuh atau swing voters atau indifferent voters. Praktik jual beli suara pada konteks desa-desa di Argentina mewujudkan diri pada beragam bentuk, seperti materi uang, barang-barang kebutuhan, misalnya makanan, pakaian, bahkan juga material seperti bangunan, hingga ke pemberian minuman anggur berkualitas tinggi. ${ }^{13}$

Masih pada studi Callahan, bahwa apa yang terjadi di Argentina berlangsung pula di Nigeria. Pada negara ini, praktik jual beli suara dilaksanakan guna mendapatkan keunggulan dalam kompetisi elektorasi di tingkat lokal. Praktik jual beli suara melibatkan banyak elit atau tokoh terpandang di wilayah lokal untuk secara terangterangan membeli hak suara dari masyarakat. Material uang yang beredar pada praktik ini berasal dari para donatur pengusaha terkemuka lokal di Nigeria dimana oleh Callahan disebut sebagai Godfathers. Aktifitas jual beli suara atau vote buying di Nigeria biasanya disertai pula dengan aksi-aksi intimidasi para oknum partai politik atau pejabat teras pemerintah. ${ }^{14}$

Esensi pokok studi Callahan di kedua negara tersebut yang terpenting adalah turut mengelompokkan makna terkait praktik jual beli suara yang berasal dari beragam persepsi pemilih, kandidat, maupun panitia pemilih atau penyelenggara elektorasi. Persepsi yang dominan diungkapkan mereka mengenai praktik jual beli suara atau vote buying sebagai bentuk "penyakit politik". Hal ini karena aktivitas tersebut mengandung praktik curang dan tidak jujur. Persepsi tersebut berpeluang digeser untuk dijadikan solusi bagi aksi penolakan praktik jual beli suara dengan mengidentifikasikan praktik-praktik yang koheren dengan nilai-nilai demokrasi borjuis. Persepsi ini mengandung imajinasi bahwa demokrasi borjuis merupakan praktik nir demokrasi . Hal ini karena berpotensi mengeliminasi calon pemimpin yang memiliki kecakapan oleh perilaku gangster atau disebut sebagai elit kelas menengah. Elit inilah yang secara faktual dinilai memiliki keunggulan secara material hanya saja bakat kepemimpinannya sangat minim. Persepsi ini secara intensif dan massif dicitrakan dan digencarkan media massa sehingga pada suatu waktu berhasil memberikan kesadaran pada masyarakat khususnya pemilih yang mengorganisir diri secara komunitas untuk melawan segala bentuk aktivitas jual beli suara. ${ }^{15}$

\footnotetext{
${ }^{13}$ William A Callahan, "The Discourse of Vote Buying and Political Reform in Thailand," Pacific Affairs 78, no. 1 (2005): 95-113, https://doi.org/https://www.jstor.org/stable/40023443.

${ }^{14}$ Ibid. Hal. 96

${ }^{15}$ Ibid. Hal. 97
} 
Kajian Sukmajati dan Aspinal menegaskan adanya faktor pendorong praktik jual beli suara sebagai salah satu varian money politics atau politik uang di Indonesia. Hal ini salah satunya akibat karakter masyarakat yang dominan melandaskan pilihannya pada alasan kepentingan kalkulasi untung rugi atau pilihan rasional secara ekonomi. Pada kalkulasi ini, calon yang memberikan iming-iming berupa barang atau uang kepada individu, keluarga atau komunitas yang berpeluang lebih unggul. Stratifikasi dan diferensiasi masyarakat Indonesia termasuk faktor yang akhirnya mempengaruhi pola pemilihan kandidat yang dianggap tidak didasarkan pada rekam jejak maupun program kerja yang ditawarkan pada masa sosialisasi atau kampanye. Iming-iming material dengan alasan rasionalitas ekonomi lebih banyak dipilih oleh pemilih bahkan dijadikan tujuan utama memilih kandidat yang menjalankan praktik jual beli suara. Masyarakat pemilih cenderung melakukan penerimaan secara material dari kandidat tertentu sehingga yang kebanyakan terjadi pada proses elektorasi di tingkat lokal adalah maximazing benefit dan minimizing cost diri para pemilih. Bagaimanapun antara kandidat dan pemilih sama-sama saling menakar kepentingan kalkulasi rasionalitas ekonominya masing-masing, mana yang dianggap lebih menguntungkan bagi mereka.

Masyarakat pemilih akan berpreferensi terhadap calon yang menyertakan atau memberikan material ekonomi baik dalam bentuk uang atau bantuan sembako, dan lain sebagainya. Pemilih dari kalangan ini tentu tidak akan mempertimbangkan calon yang tidak memberikan keuntungan bagi masyarakat pemilih. Kategorisasi praktik politik uang pada studi Sukmajati dan Aspinal ini didasarkan pada ikatan kesukuan, agama, umur, pekerjaan, jenis kelamin, ormas, dan penghasilan, sedikit banyak dengan yang distudikan oleh Callahan. Peluang-peluang bagi terjadinya praktik jual beli suara ini merupakan bentuk yang berpotensi mengancam demokrasi substansial maupun prosedural. ${ }^{16}$

Artikel ini memiliki perbedaan sekaligus memiliki nilai strategis dari studi-studi yang sudah ada sebelumnya khususnya dari segi focus. Studi-studi terkait praktik vote buying pada pemilihan perbekel di Bali masih minim dilakukan termasuk pula dalam upaya-upaya pereduksiannya. Minimnya studi ini termasuk jarangnya kajian secara intens yang dilakukan oleh lembaga-lembaga penyelenggara elektorasi di negeri ini, seperti badan atau lembaga penyelenggara elektorasi (pemilihan umum), badan independen pemantau pemilu, organisasi masyarakat sipil, termasuk para akademisi dimana seharusnya secara intens melakukan analisis atas peluang terjadinya proses jual beli suara dalam praktik elektorasi khususnya di tingkat desa, seperti pemilihan perbekel di Bali. Situasi ini tentunya menjadi ironis mengingat kondisi desa sekarang secara faktual administratif memperoleh sumber pembiayaan rutin setiap tahun dari pemerintah pusat. Pembiayaan rutin ini adalah alokasi dana desa yang justru berpeluang membuka lebar celah terjadinya praktik jual beli suara, namun sekaligus upaya preventifnya untuk melakukan pencegahan dengan menerapkan praktik akuntabilitas dalam pemilihan perbekel.

Studi tentang analisis celah terjadinya aktifitas jual beli suara (vote buying) pada pemilihan kepala desa di Bali, berusaha menampilkan gagasan terkait upaya

16 Takeuchi, “Vote Buying, Village Elections, and Authoritarian Rule in Rural China: A GameTheoretic Analysis." 
penanganannya. Tulisan ini bertujuan untuk menganalisis celah terjadinya potensi terjadi praktik jual beli suara atau vote buying dalam pemilihan kepala desa atau perbekel di Kabupaten Tabanan, Provinsi Bali. Eksplorasi akan dilakukan terhadap aspek regulasi, tanggapan (persepsi), ragam benturan yang terjadi di masyarakat serta pada upaya pereduksiannya.

\section{Metode Penelitian}

Studi dalam artikel jurnal ini merefleksikan penelitian hukum empiris (emprical legal research) yang menganalisis implementasi hukum dalam realitasnya di masyarakat. Pada penelitian ini, pengaruh ilmu sosial terhadap disiplin ilmu hukum menjadi kata kunci penting. Kata empiris merujuk pada kebenaran yang dapat dibuktikan pada alam kenyataan atau dirasakan oleh panca indera. Penelitian hukum empiris mengajak para penelitinya tidak hanya memikirkan masalah-masalah hukum yang bersifat normatif (law as written in book), atau bersifat teknis dalam mengoperasionalisasikan peraturan hukum sebagai proses mekanis, melainkan berusaha memahami pula sebagai gejala sosial dan berkaitan dengan perilaku individu di masyarakatnya yang unik serta tidak hanya diteliti secara preskriptif, melainkan pula secara deskriptif. ${ }^{17}$

Dalam penelitian ini, hukum yang dimaksud adalah norma-norma yang tertuang di dalam Peraturan Menteri Dalam Negeri Republik Indonesia Nomor 65 Tahun 2017 tentang Perubahan atas Permendagri Nomor 112 Tahun 2014 tentang Pemilihan Kepala Desa (selanjutnya disebut Permendagri No. 65/2017) dan Peraturan Daerah Kabupaten Tabanan Nomor 1 Tahun 2019 tentang Perubahan Kedua atas Peraturan Daerah Nomor 5 Tahun 2016 tentang Pemilihan, Pengangkatan, dan Pemberhentian Perbekel (selanjutnya disebut Perda Kabupaten Tabanan No. 1/2019).

Selain itu, artikel ini juga mengombinasikan dengan metode penelitian ilmu sosial yang dideskripsikan dari hasil riset kualitatif yang dilakukan di dua desa yang berada di wilayah administratif Kabupaten Tabanan. Strategi riset yang diambil adalah studi kasus dengan mendeskripsikan terkait pemilihan perbekel. Fokus kajian adalah seputar celah terjadinya potensi terjadi praktik jual beli suara atau vote buying dalam pemilihan kepala desa atau perbekel di Bali serta upaya penanganannya. Teknik penentuan informan dilakukan melalui teknik wawancara dan dokumentasi, yaitu melalui pemanfaatan dokumen media massa online terkait pemberitaan praktik vote buying. Teknik wawancara dilakukan secara purposive sampling, dimana penulis melakukan wawancara terhadap pihak yang dianggap memiliki kompetensi terkait bahasan studi ini. Melalui teknik wawancara ini, penulis menemui dan melakukan wawancara terhadap narasumber, di level Pemerintah Kabupaten Tabanan, seperti lembaga atau dinas maupun badan yang menyelenggarakan pemilihan kepala desa atau perbekel serentak. Selanjutnya setelah melakukan wawancara dari pihak pemerintah, penulis juga melakukan wawancara informan yang berasal dari perbekel, perangkat desa, dan tokoh masyarakat setempat. Pemilihan dua desa pada artikel ini dipilih desa yang berada di wilayah administratif Kabupaten Tabanan yang mana sebelumnya pernah melakukan pemilihan kepala desa perbekel secara langsung serta pernah terdapat

17 Depri Liber Sonata, "Metode Penelitian Hukum Normatif Dan Empiris: Karakteristik Khas Dari Metode Meneliti Hukum," Fiat Justisia Jurnal Ilmu Hukum 8, no. 1 (2014): 15-35, https://doi.org/https://doi.org/10.25041/fiatjustisia.v8no1 283. 
aduan praktik jual beli suara yang diduga dilakukan oknum calon saat proses pemilihan kepala desa (perbekel) serentak. ${ }^{18}$

Data yang terkumpul berupa tanggapan masyarakat maupun argumen pihak penyelenggara (birokrasi) yang dianalisis menggunakan frame teoritik pilihan rasional (rational choice theory) yang merupakan bagian teori kelembagaan (institutionalism theory). Pada frame ini, gagasan mendasar yang diambil penulis adalah lebih menganalisis dasar tindakan, bargaining (tawar-menawar), dan rasionalitas transaksional dalam praktik vote buying pemilihan perbekel di Bali. Merujuk pada studi Kosandi (2015), teori pilihan rasional yang berada dalam pendekatan kelembagaan menekankan bahwa berlangsungnya fenomena sosial, salah satunya praktik vote buying adalah hasil praktik interaktif yang mengadung siasat (strategi), serta tawarmenawar diantara para aktor rasional guna menangani problematika secara bersamasama. ${ }^{19}$

Data yang diperoleh penulis di lapangan pada artikel ini dianalisis dalam kapasitas pembacaan terdapatnya kepentingan antara calon dengan pemilih yang sama-sama diikat kepentingan yang asimetris. Keduanya sama-sama diikat kepentingan transaksional.

\section{Hasil dan Pembahasan}

\subsection{Aspek Normatif Pemilihan Kepala Desa di Kabupaten Tabanan}

Secara normatif, pemilihan pimpinan di level desa yaitu kepala desa atau perbekel secara serentak mengacu pada Permendagri No.65/2017. Peraturan ini kemudian diterjemahkan dalam level yang lebih rendah yaitu peraturan daerah, seperti salah satunya ditetapkan dalam Perda Kabupaten Tabanan No. 1/2019 yang berlaku untuk penyelenggaraan pemilihan kepala desa di Kabupaten Tabanan, Provinsi Bali.

Secara normatif, peraturan daerah ini ditetapkan dan diundangkan pada tanggal 14 Pebruari 2019. Peraturan daerah ini terdiri atas beberapa pasal perubahan terutama pengaturan pada Pasal 4, Pasal 5, Pasal 43, Pasal 49A, Pasal 49B, Pasal 49C Pasal 49D, Pasal 49E, dan Pasal 55. Terkait dengan substansi topik artikel ini, Perda Kabupaten Tabanan No. 1/2019 secara umum sebenarnya hanya mengatur mengenai tugas pokok dan fungsi pihak yang dianggap berwenang menangani persoalan terkait pemilihan kepala desa. Hal ini terutama pada Pasal 5 huruf (f) yaitu mengenai tugas panitia pemilihan kabupaten yang dibentuk oleh Bupati terutama dalam hal memfasilitasi penyelesaian permasalahan pemilihan perbekel tingkat kabupaten. Begitu pula pada Pasal 5 huruf (g) terkait tugas panitia pemilihan kabupaten untuk melakukan pengawasan penyelenggaraan pemilihan perbekel dan melaporkan serta membuat rekomendasi kepada Bupati; dan Pasal 5 huruf (h) tugas panitia pemilihan kabupaten melakukan evaluasi dan pelaporan pelaksanaan pemilihan.

18 Lexy J Moleong, “Metodologi Penelitian Kualitatif Edisi Revisi," Bandung: PT Remaja Rosdakarya 103 (2007).

${ }_{19}$ Meidi Kosandi, "Kontestasi Politik Dan Perimbangan Kekuasaan Dalam Perumusan Dan Implementasi UU MD3 2014," Jurnal Politik 1, no. 1 (2015): 125-54, https://doi.org/https://doi.org/10.7454/jp.v1i1.8. 
Pada intinya, pada tataran normatif, regulasi ini sebenarnya hanya melihat penyelesaian permasalahan pemilihan kepala desa hanya dari sisi makro, terbatas tugas pokok dan fungsi kepanitiaan yang dibentuk oleh pejabat lokaldan sama sekali terlepas dari usaha untuk menjelaskan detail jenis-jenis potensi kerawanan pelanggaran dalam pemilihan kepala desa, termasuk salah satunya potensi terjadinya praktik jual beli suara.

\subsection{Celah Potensi Praktik Vote Buying dalam Pemilihan Kepala Desa di Kabupaten Tabanan}

Dalam pengamatan penulis di lapangan, aturan atau regulasi di tingkat peraturan daerah dianggap oleh para informan penelitian masih abai terhadap aturan soal etika dan sanksi secara spesifik atau khusus. Regulasi di level daerah dipandang mereka terlampau mengatur tentang mekanisme pemilihan perbekel secara administratif. Halhal inilah yang kemudian secara penilaian banyak mempengaruhi masyarakat, terutama para informan, bahwa pada akhirnya perhelatan terkait perbekel dipandang sebatas menerjemahkan kepentingan pemerintah secara parsial. Menerjemahkan proses elektorasi dengan penunjukan administratif namun hanya diformat dalam bentuk pemilihan yang terkesan seolah-olah demokratis. Hal ini seperti pengaturan regulasinya yang lebih banyak menegaskan tentang kemampuan pendanaan atau penganggaran, pembentukan panitia pemilihan, masa waktu jabatan perbekel, mekanisme jabatan antar waktu, tahapan pemilihan, serta syarat administratif lainnya.

Mencermati praktik vote buying yang merujuk pengaturannya secara makro pada aturan Pemerintah Pusat khususnya Pasal 30 terkait aspek etis dan konsekuensi atas pelanggaran (sanksi) proses elektorasi kepala desa, ternyata pada proses implementasinya memiliki dinamikanya tersendiri. Apabila di level praksis, praktik ini memang sulit dideteksi karena sifatnya praktiknya yang halus dan tersembunyi. Pada tinjauannya secara yuridis bentuk-bentuk praktik vote buying ini juga ternyata memiliki peluang untuk terjadi, terutama di tataran persepsional kalangan implementator kebijakan dimana mereka mengakui bahwa beberapa klausul pada peraturan daerah justru bisa dianggap memberikan peluang ruang bagi terjadinya praktik-praktik ini.

Hal ini misalnya pengaturan pembentukan kepanitiaan antar waktu seperti yang diatur dalam Pasal 49 B Perda Kabupaten Tabanan No.1/2019 yang dinilai resisten atas intervensi atau bahkan intimidasi secara administratif oleh calon maupun pihak eksternal lainnya yang memiliki kepentingan. Dalam praktik yang terjadi, informan dari penelitian yang dilakukan penulis sebagian besar menyatakan bahwa regulasi di tingkat daerah ini memang secara yuridis telah menentukan pihak-pihak yang terlibat secara partisipatif dalam musyawarah desa dalam pengawalan proses hingga penetapan. Hal ini seperti didukung oleh pengaturan pada Pasal 49 D, dimana dinyatakan adanya keterlibatan elemen komunitas masyarakat baik secara formal maupun non formal. Elemen formal seperti pemuka adat, komunitas masyarakat di desa bersangkutan, tokoh agama, penggerak dan tokoh pendidikan di level desa. Sedangkan untuk elemen non formal, tersebar pada tokoh-tokoh yang aktif pada kelompok-kelompok (sekaa) di bidang pertanian, nelayan, pengairan, perajin, kelompok perempuan desa, hingga organisasi masyarakat sipil di bidang pendampingan masyarakat miskin dan kelompok pendampingan sesuai karakter masyarakat setempat. 
Secara implementatif pengaturan pasal-pasal ini justru dinilai atau dianggap informan masih kontradiktif. Resistensi praktik vote buying dinyatakan berpeluang luas muncul terlebih saat pihak-pihak yang memiliki kewenangan dalam pelaksanaannya, yaitu Pemerintah Kabupaten, minim mensosialisasikan secara dini terkait pemilihan perbekel secara langsung. Kurangnya sosialisasi ini yang secara persepsional di kalangan informan dianggap menjadi faktor yang turut memicu keengganan masyarakat luas untuk ikut serta dalam proses elektorasi di tingkat lokal, karena aktifitas ini selalu rawan terintervensi oleh pihak-pihak yang menjalankan praktik vote buying dalam pemenangan kompetisi politik di wilayahnya.

Mengikuti frame teoritik pilihan rasional maka janji-janji politik, yang terkemas dalam bahasa program layanan publik warga desa dari para kandidat dalam pemilihan perbekel seringkali mengkomodifikasikannya di dalam beragam bentuk praktik vote buying termasuk pemberian kompensasi berupa keuntungan material yang menguntungkan kedua belah pihak, yaitu kandidat dengan para calon pemilihnya. Kemasan praktik ini pun variatif. Beberapa diantaranya, menurut para informan penelitian, dapat berupa kompensasi (sumbangan) kepada kelompok-kelompok petani dan peternak serta sumbangan kegiatan yang bertendensi pada pengembangan kegiatan sosial kebudayaan pada kelompok (sekaa) muda-mudi pada tingkat banjar di masing-masing desa. Pemberian bantuan ini berlangsung intens, bahkan diintegrasikan dengan bansos yang ada di tingkat dewan (legislatif) kabupaten yang sarat unsur politis, terutama memobilisasi massa untuk kepentingan praktis partai politik tertentu.

Pada implementasi aturan terkait pemilihan kepada desa, klausul ini juga kerap mengalami benturan saat terdapat aktivitas yang mereduksi atau bahkan mencabut nilai-nilai positif (mis-conduct) praktik demokrasi. Di dalam konteks ini, sisi-sisi akuntabilitas elektorasi di level desa banyak diabaikan atau bahkan terabaikan. Sisi keadilan atau fairness juga tidak banyak terakomodasikan. Hal ini seperti pengabaian pengelolaan aduan tindak penyelewengan elektorasi kepala desa yang tidak terakomodasi selayaknya upaya Negara, -dalam hal ini badan pengawas pemilu atau panitia pengawas pemilu-, dalam menangani aduan pelanggaran proses pemilihan kepala daerah, seperti Bupati, Walikota, ataupun Gubernur. Wadah-wadah ini secara realitas, ternyata juga tidak memiliki, --atau tidak diberikan--, otoritas apapun dalam ranah pemilihan perbekel, meski tensi atas pelanggarannya juga memiliki peluang atas kadar pelanggaran yang berpotensi sangat tinggi. Secara faktual, mekanisme persiapan, pelaksanaan, hingga penetapan hasil elektorasi di tingkat desa menyertakan peran dominan yang berada di tangan birokrasi pemerintah vertikal, yaitu Pemerintah Kabupaten setempat. Dalam pelaksanaannya, badan, dinas, atau lembaga organik dari pemerintah kabupaten ataupun kota, seperti Badan Pemberdayaan Masyarakat dan Pemerintahan Desa (BPMPD) dan Badan Kesatuan Bangsa Politik dan Perlindungan Masyarakat. Beberapa lembaga pemerintah daerah inilah yang memiliki kekuasaan sekaligus diberikan kewenangan atas nama Bupati untuk melaksanakan pemilihan jabatan perbekel di level desa.

Secara persepsional, sebagian besar informan menyatakan bahwa kandidat yang berpeluang dalam melaksanakan aktivitas vote buying adalah oknum kepala desa atau perbekel yang sebelumnya pernah menduduki jabatan, atau oknum kandidat incumbent. Dalam aktivitas yang dilakukannya peluang berjalannya penyimpangan ini memiliki beragam bentuk dimana sifatnya mengadaptasi banyak program rutin pembangunan 
desa namun sifatnya lebih personal. Pemberian sumbangan atau bantuan yang terprogram dalam kegiatan rutin pembangunan desa biasanya teralokasikan pada kelompok-kelompok lingkar keluarga atau masyarakat. Sifat kuasa pendistribusiannya dua arah namun tidak dominatif, namun sebaliknya berjejaring atau setara. Kesetaraan ini menyiratkan terdapatnya peluang transaksional antara kandidat dengan individu atau kelompok pemilih. Aktivitas jual beli suara ini mengambil aksinya pada masa sosialisasi, hingga menjelang pelaksanaan pemilihan suara, meski sebagian besar informan menyatakannya sebagai bentuk pencideraan demokrasi dengan menyertakan kepentingan pilihan rasional di masing-masing pihak. Kondisi ini pada sisi yang sama dipersepsikan sebagai dampak in-kosistensi praktik demokrasi di tingkat lokal akibat pengabaian aspek sosialisasi yang matang di kalangan warga. Bahkan terkadang pula, terjadi pemotongan akses informasi dan sosialisasi sebagaimana warga seharusnya bisa mendapatkan porsi yang transparan sama halnya dengan proses elektorasi di tingkal lokal lainnya, seperti pemilukada ataupun pemilu legislatif.

Praktik jual beli suara atau vote buying ini meski menyimpang namun oleh sebagian besar informan masih dinilai atau dipersepsikan melanggar atau menciderai berjalannya prinsip-prinsip keadilan dalam penyelenggaraan praktik berdemokrasi di tingkat lokal. Dalam ranah persepsional, sebagian besar informan masing menganggap aturan regulasi terkait pemilihan perbekel memiliki muatan ambiguitas, terlebih saat aturannya diterjemahkan pada regulasi di level daerah, seperti Peraturan Daerah (Perda). Pada satu sisi, menekankan adanya demokrasi yang menjamin partisipasi dan pemilihan serentak, namun di sisi yang sama masih memiliki kendali yang besar dari pengaturan secara administratif dari pemerintah vertikal termasuk ketiadaan atau abainya pasal yang mengatur secara detail mengenai kapasitas sanksi terutama dalam mengatasi peluang terjadinya praktik vote buying.

Peluang vote buying dan pelanggaran pemilihan perbekel dipersepsikan sebagian besar informan dilakukan oleh oknum calon perbekel yang sedang menjabat atau incumbent. Hal ini terlebih kewenangannya dalam mengeksekusi anggaran pembangunan di desa setempat sehingga bisa menghadirkan peluang resiko yang dipolitisir untuk kepentingan pencalonan. Dalam teori pilihan rasional, peluang atas terjadinya praktik vote buying ini salah satunya justru bisa tercipta dari motif pemanfaatan anggaran publik (dana) desa. Di dalamnya telah terdapat proses tawar-menawar yang sifatnya transaksional dan politis dimana berpeluang dimainkan oknum kandidat perbekel incumbent beserta aktor di sekeliling elit pemerintahan desa yang notabene sebagian dari mereka berposisi sebagai panitia pemilihan. Potensi kerawanan inilah yang kemudian disebut sebagai vote trading. Vote trading ini adalah salah satu bentuk ekses yang muncul dari praktik vote buying dimana terdapat potensi transaksi antara oknum calon kandidat dengan oknum penyelenggara pemilihan perbekel. ${ }^{20}$

Terdapat peluang interaksi strategi dan negosiasi antara aktor-aktor rasional yang berusaha untuk mendapatkan pemanfaatan optimal pada masing-masing pihak. Kepentingan antara calon dalam pemilihan perbekel dengan para pemilihnya samasama diikat kepentingan yang saling asimetris. Asmietris di sini kedua belah pihak sama-sama diikat kepentingan transaksional yang relasi kuasanya sifatnya 'tidak lagi' mendominasi melainkan berjejaring. Pada praktik-praktik ini biasanya banyak terimplementasi dalam pemanfaatan program yang menyertakan ikatan loyalitas

${ }^{20}$ Sukmajati and Aspinal, "Politik Uang Di Indonesia." 
untuk memilih secara klientilistik. Terdapat kewenangan patron yang biasanya diambil oleh kandidat calon incumbent dengan para klien-kliennya, termasuk calon pemilih, yang secara oportunistik diikat oleh kepentingan pemanfaatan anggaran. Kondisi ini disebut atau diistilahkan para informan sebagai pemanfaat program secara by name by address (dengan nama dan dengan alamat) secara jelas. Beberapa informan menyebutkan praktik vote buying menjadi berpeluang membentuk dirinya pada dua negosiasi. Pertama, negosiasi yang tidak kentara dengan praktik lobby di belakang layar. Kedua, negosiasi yang potensinya menjelma menjadi bahasa program rutin yang dilaksanakan oleh para aparatur birokrasi desa, seperti memberikan bantuan kepada perkumpulan para peternak maupun para petani, pemberian sumbangan program kegiatan pengembangan sosial budaya pada perkumpulan (sekaa) mudamudi di tingkat banjar, hingga pemberian bantuan perbaikan sarana peribadatan.

Bentuk-bentuk bantuan ini apabila mengikuti kategorisasi yang pernah dilakukan pada studi Aspinal dan Rahman, jelas bahwa praktik vote buying dalam pemilihan perbekel di dalamnya terdapat sistem nilai yang menggerakkannya seperti meliputi komponen pelaku dan strategi. Komponen pelaku terdiri atas aktor yang menjalankan vote buying, seperti oknum yang menjalankannya secara langsung (direct actor). Oknum ini seperti para kelompok atau yang menyukseskan salah satu kandidat kepala desa (perbekel) termasuk pula para petaruh atau yang disebut bandar judi (bebotoh). Sedangkan untuk oknum yang menjalankannya secara tidak langsung (indirect actor) adalah oknum kandidat calon kepala desa (perbekel), beserta aparatur birokrasi, baik di level vertikal maupun setara di level desa yang berada dalam lingkar relasi kuasa kepentingan dengan kandidat. Aktor inilah yang kemudian menegosiasikan aspekaspek strategis, seperti turut memainkan bentuk-bentuk intervensi terhadap institusi regulasi atau aturan main elektorasi, praktik memberikan sumbangan uang maupun non uang, seperti dengan pemberian sumbangan program pembangunan atau rehabilitasi fisik, hingga pertukaran aspek non material yang mengarah pada pemberian posisi jabatan sebagai perangkat desa. ${ }^{21}$

Tabel 1

Pola Kerawanan Vote Buying

\begin{tabular}{cl}
\hline Aspek & \multicolumn{1}{c}{ Bentuk dan Praktik } \\
\hline Komponen Pelaku & Pelaku Langsung : Dilakukan oleh tim \\
& sukses kandidat, bandar judi atau petaruh \\
& (bebotoh) yang ikut mendukung pembiayaan \\
& salah satu kandidat.
\end{tabular}

Pelaku Tidak Langsung : Birokrat pengurus atau perangkat desa yang berada dalam lingkar kepentingan kandidat kepala desa incumbent

Strategi

Uang : Suap berupa uang tunai yang dibagikan oleh kandidat jelang pemilihan kepada para calon pemilihnya.

Barang: Pemberian bantuan berupa material

\footnotetext{
${ }^{21}$ Aspinall and Rohman, "Village Head Elections in Java: Money Politics and Brokerage in the Remaking of Indonesia's Rural Elite."
} 
dari kandidat kepada individu, keluarga, atau kelompok orang sebagai calon pemilih. Biasanya pula pemberian ini termanifestasi pada program rutin pemerintah desa yang di danai oleh dana desa.

Pertukaran Simbolik non Material : Kandidat kepala desa menawarkan sejumlah jabatan sebagai perangkat desa atau pimpinan proyek program-program yang dibiayai oleh dana desa

Pada konteks ini upaya-upaya pengakomodasian aspirasi yang tertuang dalam regulasi pada level daerah jusru dianggap sebagian besar informan hanya sekedar menjadi idealisasi saja karena aspek substantif regulasi ini tidak disertai kondisi pendidikan politik warga yang baik. Kondisi partisipasi dan pengawasan warga terhadap proses ini dipersepsikan masih timpang dan tidak berjalan beriringan bahkan untuk mampu mengimbangi wacana (discourse) vote buying yang keberadaannya justru telah banyak mengadaptasi dan mengambil beragam bentuk. Kondisi yang seharusnya memampukan warga untuk melakukan perencanaan, pengawasan, serta evaluasi, lebih banyak dinilai informan justru diciderai oleh praktik vote buying atau praktik pelanggaran-pelanggaran lainnya.

Para informan yang ditemui penulis secara dominan masih memiliki persepsi yang menyatakan bahwa minimnya akses informasi dan sosialisasi pada publik desa secara luas akhirnya dianggap sebagai pendorong keacuhan masyarakat untuk berpartisipasi aktif dalam proses elektorasi di level desa. Saat persaingan diantara kandidat kecil atau terbatas, maka hal ini justru memberikan peluang ruang gerak yang luas bagi terjadinya praktik vote buying. Seringkali praktiknya susah terdeteksi meski oleh warga level akar rumput sendiri sekalipun. Praktik-praktik vote buying akhirnya banyak dipengaruhi oleh pewacanaan yang berkembang dan keberadaannya adaptif di dalam menyesuaikan perkembangan kepentingan atau kebutuhan para kelompok sasaran.

Hanya saja pada sisi ini, beberapa informan yang ditemui penulis juga menawarkan beberapa solusi terutama dalam mengupayakan bagaimana agar rekam jejak calon yang bersaing dalam kompetisi pemilihan perbekel, bisa memiliki sisi akuntabilitas yang kuat. Website dalam portal resmi desa adalah bagian kompromi atas bertemunya praktik pengontrolan masyarakat yang berjalan sebagai konsekuensi pengawasan atas program-program pembangunan, termasuk diadaptasi di dalam pelaksanaan pemilihan perbekel serentak.

Solusi yang ditawarkan sebagian besar informan adalah menampilkan konten-konten terkait elektorasi secara online dan bisa diakses publik secara luas. Misalnya, tawaran menampilkan profil masing-masing kandidat, penyampaian visi, misi serta program kerja kandidat, informasi identitas aset yang dimiliki masing-masing calon, hingga rekam jejak prestasi kepemimpinan publik yang dimiliki kandidat. Semua data ini diharapkan para informan bisa diakses secara mudah untuk memenuhi berjalannya prinsip-prinsip akuntabilitas terutama dalam proses berjalannya elektorasi di level desa. Semua data ini diharapkan bisa ditampilkan secara transparan pada portal atau website milik desa dan senantiasa terupdate baik dari proses persiapan, hingga jelang 
proses elektorasi dilaksanakan.

Profil dari calon bahkan bisa menampilkan detail pendidikan, profil keluarga, dan rekam jejak kepemimpinan yang pernah disandang oleh masing-masing calon. Penyampaian visi, misi serta program dari masing-masing calon menjadi elemen penting untuk ditampilkan pada website ini. Hal ini mengingat kepala desa atau perbekel adalah jabatan yang identik dengan pihak yang memegang atau pengendali kemudi pemerintahan dan sekaligus pembangunan desa. Untuk itu warga desa harus mengetahui secara menyeluruh rekam jejak para calon pemimpinnya secara jelas dan terukur. Program yang ditawarkan harus terukur di dalam masing-masing indikator capaian dimana hal ini untuk menghindari cidera janji masing-masing calon apabila nantinya terpilih sebagai pemimpin formal di desanya.

Hal yang juga tidak bisa dikesampingkan adalah publikasi aset yang dimiliki oleh masing-masing calon dimana hal ini adalah untuk menghindarkan peluang tindak penyimpangan KKN (Korupsi, Kolusi, dan Nepotisme). Seluruh upaya publikasi ini bisa menjadi bagian dari website yang dimiliki masing-masing desa bersangkutan, selain masih membuka peluang publikasi yang konvensional seperti pamflet-pamflet berisi rekam jejak, program kerja masing-masing kandidat calon di desa bersangkutan.

Semua informasi ini tentunya harus senantiasa diintensifkan dan diperbaharui, baik pada tahap persiapan hingga menjelang pelaksanaan elektorasi. Keterlibatan warga dalam mengakses seluruh informasi ini juga tentunya memutlakkan adanya sosialisasi yang intensif dan massif dari pihak penyelenggara yaitu pemerintah daerah. Komitmen atas upaya ini tidak lain adalah untuk menjunjung tinggi sisi akuntabilitas, transparansi, keadilan, dan profesionalitas pelaksanaan elektorasi di tingkat desa bisa teraktualisasikan. Apabila upaya ini dijalankan maka aspek demokrasi lokal yang diidealkan bisa dibangun tentunya pada basis kekuasaan di level akar rumput negara kita, yaitu desa.

\section{Kesimpulan}

Implementasi Peraturan Menteri Dalam Negeri Republik Indonesia Nomor 65 Tahun 2017 tentang Perubahan atas Permendagri Nomor 112 Tahun 2014 tentang Pemilihan Kepala Desa dan Peraturan Daerah Kabupaten Tabanan Nomor 1 Tahun 2019 tentang Perubahan Kedua atas Peraturan Daerah Nomor 5 Tahun 2016 tentang Pemilihan, Pengangkatan, dan Pemberhentian Perbekel masih turut memberikan peluang praktik vote buying dalam pemilihan kepala desa (perbekel). Ketiadaan pengaturan sanksi secara tegas pada pasal-pasal kedua regulasi ini justru dianggap menyertakan ruang yang dimungkinkan untuk dinegosiasikan oleh para oknum bagi terjadinya praktik ini. Regulasi yang mengatur pemilihan kepala desa akhirnya hanya dianggap sebagai instrumen yang turut melahirkan praktik demokrasi yang ambigu. Hal ini karena meski pengaturan administratifnya masih berada dalam dominasi pemerintah vertikal melalui pengaturan tugas pokok dan fungsi panitia pemilihan, namun sebagian informan menganggapnya cenderung abai terhadap pengaturan soal sanksi berikut jenis-jenis pelanggarannya. Terlebih, saat praktik vote buying ini ditengarai pula rentan terjadi di kalangan oknum perbekel yang berpeluang mencalonkan kembali (incumbent). Peluang ini biasanya turut menyertakan penyimpangan anggaran desa bagi kepentingan proses kandidasi oknum calon bersangkutan maupun beragam bentuk penyimpangan lainnya. Langkah yang hendaknya bisa diambil para 
pemangku kepentingan dalam menjamin pelaksanaan kedua regulasi tersebut dan mengantisipasi pula terjadinya praktik vote buying adalah dengan menyertakan aturan pelaksananya yang tegas berikut penetapan sanksinya yang jelas dan terukur serta disosialisasikan secara terbuka kepada masyarakat. Selain itu, upaya pereduksian praktik vote buying ini bsia dilakukan pula dengan pembuatan website desa yang memuat rekam jejak kandidat yang bisa diakses secara transparan oleh masyarakat desa bersangkutan maupun publik secara luas.

\section{Ucapan terima Kasih (Acknowledgments)}

Penulis mengucapkan terima kasih kepada Lembaga Penelitian dan Pengabdian Kepada Masyarakat (LPPM) Universitas Udayana yang telah mendanai kegiatan ini melalui skim Hibah Unggulan Udayana serta beberapa narasumber dalam penelitian yang sudah dilakukan oleh penulis.

\section{Daftar Pustaka}

Buku

Moleong, Lexy J. "Metodologi Penelitian Kualitatif Edisi Revisi." Bandung: PT Remaja Rosdakarya 103 (2007).

Sukmajati, Mada, and E Aspinal. "Politik Uang Di Indonesia." Yogyakarta: PolGov, 2015.

\section{Jurnal}

A Shahab. "Vote Buying Dalam Pemilihan Kepala Daerah (Pilkada) Studi Kasus Pilkada Surabaya Dan Pilkada Kabupaten Blitar Tahun 2010." Jurnal Jejaring Administrasi Publik 4, no. 2 (November 2012): 118-24. http://journal.unair.ac.id/ADMP@vote-buying-dalam-pemilihan-kepaladaerah-(pilkada)-studi-kasus-pilkada-surabaya-dan-pilkada-kabupaten-blitartahun-2010-article-9418-media-81-category-8.html.

Aspinall, Edward, and Noor Rohman. "Village Head Elections in Java: Money Politics and Brokerage in the Remaking of Indonesia's Rural Elite." Journal of Southeast Asian Studies 48, no. 1 (2017): 31-52. https: //doi.org/https://doi.org/https://doi.org/ 10.1017/S0022463416000461.

Bowie, Katherine A. "Vote Buying and Village Outrage in an Election in Northern Thailand: Recent Legal Reforms in Historical Context." The Journal of Asian Studies 67, no. 2 (2008): 469-511. https://doi.org/10.1017/S0021911808000673.

Callahan, William A. "The Discourse of Vote Buying and Political Reform in Thailand." Pacific Affairs 78, no. 1 (2005): https://doi.org/https://www.jstor.org/stable/40023443.

Halili, Halili. "Praktik Politik Uang Dalam Pemilihan Kepala Desa." Jurnal Penelitian Humaniora 14, no. 2 (October 1, 2009): 99-112. https://journal.uny.ac.id/index.php/humaniora/article/view/21770.

Kosandi, Meidi. "Kontestasi Politik Dan Perimbangan Kekuasaan Dalam Perumusan Dan Implementasi UU MD3 2014." Jurnal Politik 1, no. 1 (2015): 125-54. https://doi.org/https://doi.org/10.7454/jp.v1i1.8.

Sonata, Depri Liber. "Metode Penelitian Hukum Normatif Dan Empiris: Karakteristik Khas Dari Metode Meneliti Hukum." Fiat Justisia Jurnal Ilmu Hukum 8, no. 1 (2014): 15-35. https://doi.org/https://doi.org/10.25041/fiatjustisia.v8no1.283. 
Takeuchi, Hiroki. "Vote Buying, Village Elections, and Authoritarian Rule in Rural China: A Game-Theoretic Analysis." Journal of East Asian Studies 13, no. 1 (2013): 69-105. https://doi.org/https://doi.org/10.1017/S1598240800008535.

\section{Website}

Ali Mustofa. "Baru Dilantik Langsung Dicopot Jadi Perbekel, Ashari Diganjar 15 Bulan." Accessed December 4, 2020. https://radarbali.jawapos.com/read/2019/12/19/170880/baru-dilantiklangsung-dicopot-jadi-perbekel-ashari-diganjar-15-bulan.

Kompas. "Besaran Politik Uang Pilkades Di Demak Rp 50.000-500.000 per Pemilih." Accessed January 31, 2021. https://regional.kompas.com/read/2017/10/02/08355381/besaran-politikuang-pilkades-di-demak-rp-50000-500000-per-pemilihan.s.

- - - "Pilkada Langsung Serentak: Sejarah Dan Perkembangannya Di Indonesia." Accessed April 18, 2021. https://kompaspedia.kompas.id/baca/paparantopik/pilkada-langsung-serentak-sejarah-dan-perkembangannya-di-indonesia.

Widnyani. "KPU Gianyar Gelar Publikasi Hasil Riset Tingkat Partisipasi Pemilih Pemilu 2014 - Situs Resmi Komisi Pemilihan Umum Kabupaten Gianyar." Accessed December 5, 2020. http://www.kpugianyarkab.go.id/berita/bacaberita/95/kpu-gianyar-gelar-publikasi-hasilriset-tingkat-partisipasi-pemilih-pemilu-2014.html.

\section{Undang-Undang dan Peraturan}

Undang-Undang Nomor 6 Tahun 2014 tentang Desa

Undang-Undang Republik Indonesia Nomor 7 Tahun 2017 tentang Pemilihan Umum

Peraturan Menteri Dalam Negeri Republik Indonesia Nomor 65 Tahun 2017 tentang Perubahan atas Permendagri Nomor 112 Tahun 2014 tentang Pemilihan Kepala Desa

Peraturan Daerah Kabupaten Tabanan Nomor 1 Tahun 2019 tentang Perubahan Kedua atas Peraturan Daerah Nomor 5 Tahun 2016 tentang Pemilihan, Pengangkatan, dan Pemberhentian Perbekel.

Peraturan Badan Pengawas Pemilihan Umum Republik Indonesia Nomor 8 Tahun 2020 tentang Penanganan Pelanggaran Pemilihan Gubernur dan Wakil Gubernur, Bupati dan Wakil Bupati, serta Walikota dan Wakil Walikota 